\title{
Urinsyrekrystaller
}

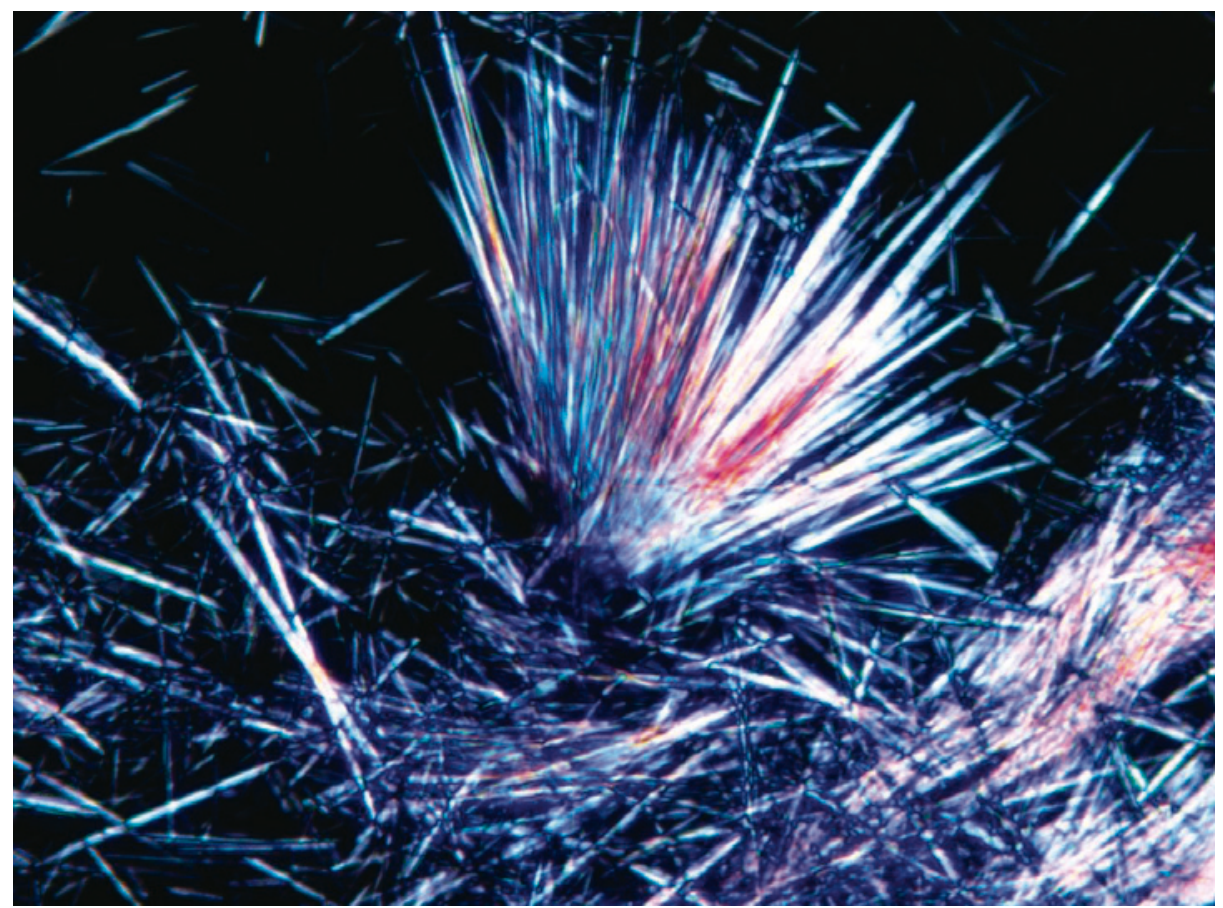

Undersøkelse av leddvæske gjøres regelmessig som ledd i utredningen av hovne ledd. Ved mikroskopisk undersøkelse vurderes cellulariteten, hvilke typer celler som er til stede og om det foreligger krystaller. For å vurdere krystaller er det nødvendig med et polariseringsfilter i mikroskopet.

Ved urinsyregikt finner man oftest kun spredte urinsyrekrystaller i leddvæsken, men ved sjeldne tilfeller kan det være betydelig akkumulasjon. Da bør man overveie om materialet er fra et tofus i relasjon til leddet. Tofus er en knutet ansamling av urinsyrekrystaller (monosodium urat monohydrat krystaller) med påfølgende fremmedlegemereaksjon (1). De kan forekomme i alle anatomiske lokalisasjoner, men oftest rundt ledd.

Leddvæsken kan prepareres som direkte utstryk eller som et nedspunnet produkt. Dette vil påvirke både cellulariteten og krystalltettheten i preparatet, avhengig av det nedspunnede volumet.
Urinsyrekrystaller kjennetegnes ved at de er nåleformede og sterkt dobbeltbrytende i polarisert lys, mens krystaller av kalsiumpyrofosfatdihydrat som man finner ved kondrokalsinose har mer romboid utseende og mindre dobbeltbrytende egenskaper $(2,3)$.

Ved påviste urinsyrekrystaller i leddvæske foreligger det per definisjon urinsyregikt, og spesifisiteten til undersøkelsen er derfor høy. Sensitiviteten er noe lavere, og det kan blant annet forklares ved manglende trening $i$ mikroskopiske teknikker for å påvise urinsyrekrystaller (4).

Bildet viser massiv opphopning av urinsyrekrystaller sett $\mathrm{i}$ polarisert lys ved $400 \mathrm{x}$ forstørrelse.

\section{Marius Lund-Iversen}

marius@lund-iversen.com

Avdeling for patologi

Oslo universitetssykehus
Marius Lund-Iversen (f. 1974) er spesialist i patologi og overlege.

Forfatter har fylt ut ICMJE-skjemaet og oppgir ingen interessekonflikter.

\section{Litteratur}

1. Dorlands 's illustrated medical dictionary. 28. utg London: Elsevier Health Sciences, 1994.

2. Pascual E. The diagnosis of gout and CPPD crystal arthropathy. Br J Rheumatol 1996; 35: 306-8.

3. Ivorra J, Rosas J, Pascual E. Most calcium pyrophosphate crystals appear as non-birefringent. Ann Rheum Dis 1999; 58: 582-4.

4. Lumbreras B, Pascual E, Frasquet J et al. Analysis for crystals in synovial fluid: training of the analysts results in high consistency. Ann Rheum Dis 2005; 64: 612-5.

Mottatt 19.5. 2014, første revisjon innsendt 9.9. 2014, godkjent 23.9. 2014. Redaktør: Siri Lunde Strømme.

Engelsk oversettelse på www.tidsskriftet.no 